\title{
Determinants of Earnings from Tea Export in Kenya: 1980-2011
}

\section{Agnes Kinya Muthamia, Willy Muturi}

Department of Economics, Accounting and Finance; Jomo Kenyatta University of Agriculture and Technology, Nairobi, Kenya

\section{Email address:}

agnesmuthamia@yahoo.com (A. Muthamia),mmuturi2001@yahoo.com (W. Muturi)

\section{To cite this article:}

Agnes Kinya Muthamia, Willy Muturi. Determinants of Earnings from Tea Export in Kenya: 1980-2011. Journal of World Economic Research. Vol. 4, No. 1, 2015, pp. 15-22. doi: 10.11648/j.jwer.20150401.12

\begin{abstract}
Fluctuation of tea export earnings affects the profitability of firms in the sector and therefore farmers' earnings (bonus). To this end, there is dire need for stabilizing the earnings to farmers hence need to know the key factors which could be targets for policy and hence the need for this study. The dependent variable was tea export earning while the independent variables were real exchange rate, foreign income and inflation. To enhance accuracy and credibility of this study, control variables used include unit prices of tea, agriculture value added as well as export of goods and services. The specific objectives included exploring the effect of real exchange rate on tea export earnings; the effect of inflation rate, and establishing the effect of foreign income of major trading partners on tea export earnings. Various regression methods are used to test the research hypothesis, including unit root tests, co integration, and error correction model. The long run and short run analysis of these variables is taken to account. Findings ascertain that indeed the model gives a good description of the variables. Foreign income has an indirect relationship with tea export earnings. On the other hand, they are all significant except inflation. There is a direct relationship between tea export earnings and real exchange rate, tea price, export of goods and services, and agriculture value addition. The study recommends tea exporters to hedge against foreign exchange risk through derivative markets. It encourages stakeholders to engage in marketing and value addition. Value addition is a sustainable solution to ensure stability of earnings from tea exports in the country. Finally, strong monetary policies are recommended to enhance price stability and tea export earnings. This is because such policies should curb the problem of extensive volatility of inflation and exchange rates.
\end{abstract}

Keywords: Export Earnings, Real Exchange Rates, Inflation, Tea Prices, Value Addition

\section{Introduction}

As an open economy, Kenya considers exchange rate as key macroeconomic policy instrument that ensures export promotion and economic growth. The magnitude of the international flow of goods, services and assets is impossible to ignore (Chechetti, 2008). Despite experiencing mixed results over the years, agriculture remains the mainstay of the Kenyan economy. Ministry of Agriculture (2009) further indicates that Cross-country estimates show that GDP growth originating from agriculture is at least twice as effective in reducing poverty as GDP originating outside agriculture. Kenya Vision 2030 (2007) strategy has identified agriculture as one of the six key economic sectors expected to drive the economy to a projected 10 percent economic growth annually over the next two decades through promotion of an innovative, commercially-oriented and modern agriculture.
The role of exports in economic development has been widely acknowledged. Ideally, export activities stimulate growth in a number of ways including production and demand linkages, economies of scale due to larger international markets, increased efficiency, adoption of superior technologies embodied in foreign-produced capital goods, learning effects and improvement of human resources, increased productivity through specialization and creation of employment (Were et al., 2002). Generally, Kenyan exports have been constrained by unfavorable international terms of trade. Developed countries in particular, continue to impose prohibitive tariff and non-tariff barriers. These include declining commodity prices, biased trade agreements and the use of agricultural subsidies in support of farmers in developed economies. Additionally, international trade negotiations such as those under World Trade Organization and the Economic Partnership Agreements (EPAs) have been slow and have achieved little progress in the last decade 
(Ministry of Agriculture, 2009). According to (Ministry of Agriculture, 2009), Kenyan farmers export semi-processed, low-value produce, which accounts for 91 percent of total agriculture-related exports. Writing in the same vein, Were et al. (2002) asserts that Kenya's exports are still dominated by primary agricultural products.

Tea is sold in USD spot through automated public auction in Mombasa (TBK, 2012). East Africa Tea Trade Auction (EATTA) runs the Mombasa tea auction that is the second largest tea auction in the world after the Colombo auction. Of the tea exported globally, 32\% passes through the Mombasa auction (EATTA, 2012). Kenyan tea is sold to the world market in bulk and used for blending lower quality teas from other countries (Tea Research Foundation Kenya, 2009). Therefore, this results in lower prices for Kenyan tea. The industry has remained stable, with increases in production levels and therefore earnings from exports.

Kenya is the largest producer of tea in Africa, and it has quadrupled its exports over the last decade. Currently, Kenya prides itself as one of the world's leading black Tea producers with Pakistan, the UK and Egypt being the biggest buyers (Tea Board of Kenya, 2012). Computations indicate that Major tea trading partners considered herein include UK, Egypt and Pakistan which command $66.65 \%$ of the export share as computed from 1994 to 2011 demonstrated in the figure 1 below.

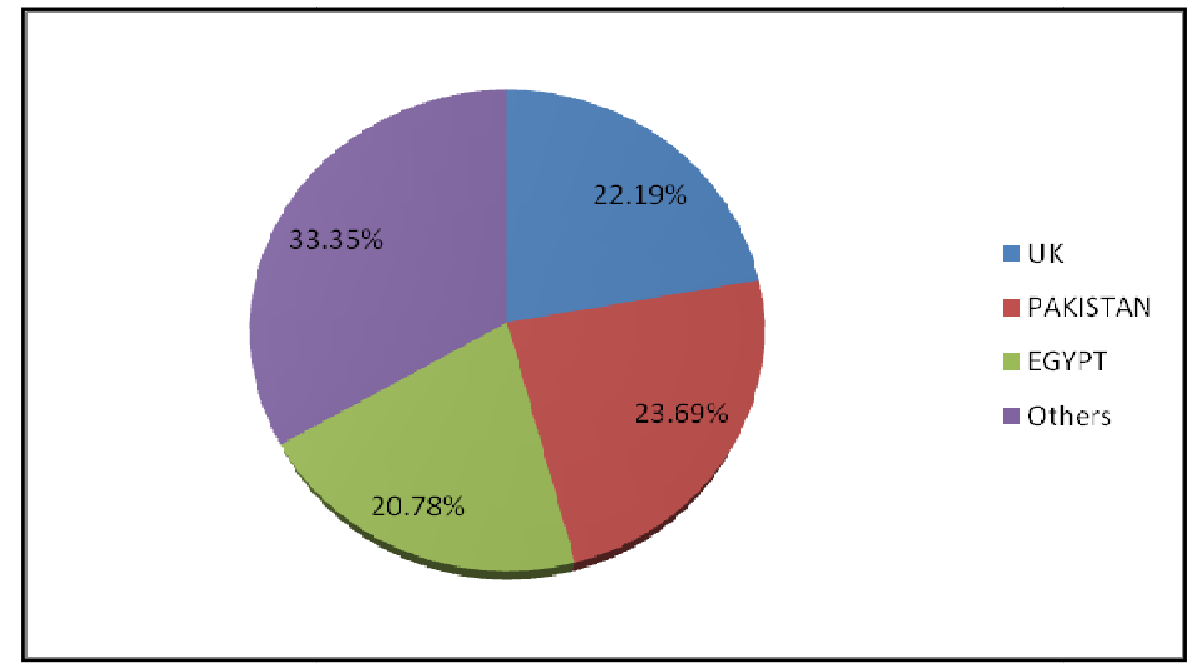

Figure 1. Major trading partners of tea exports from Kenya.

According to Tea Research Foundation Kenya (2011), Kenya is ranked third in annual tea production after China and India. The tea produced in Kenya accounts for about $10 \%$ of the world production and about $22 \%$ of the export share. As regards tea exports, Kenya has been second largest exporter in 2004 (after Sri Lanka), the same constellation that prevailed in 1985 (Kenya Vision 2030, 2007). It is therefore considered to be a major exchange earner for the country and contributes significantly to the country's GDP. The graph below demonstrates substantial contribution of tea exports to the country's GDP. 1981 recorded a low of $1.97 \%$ while 1993 recorded a high of $5.6 \%$.

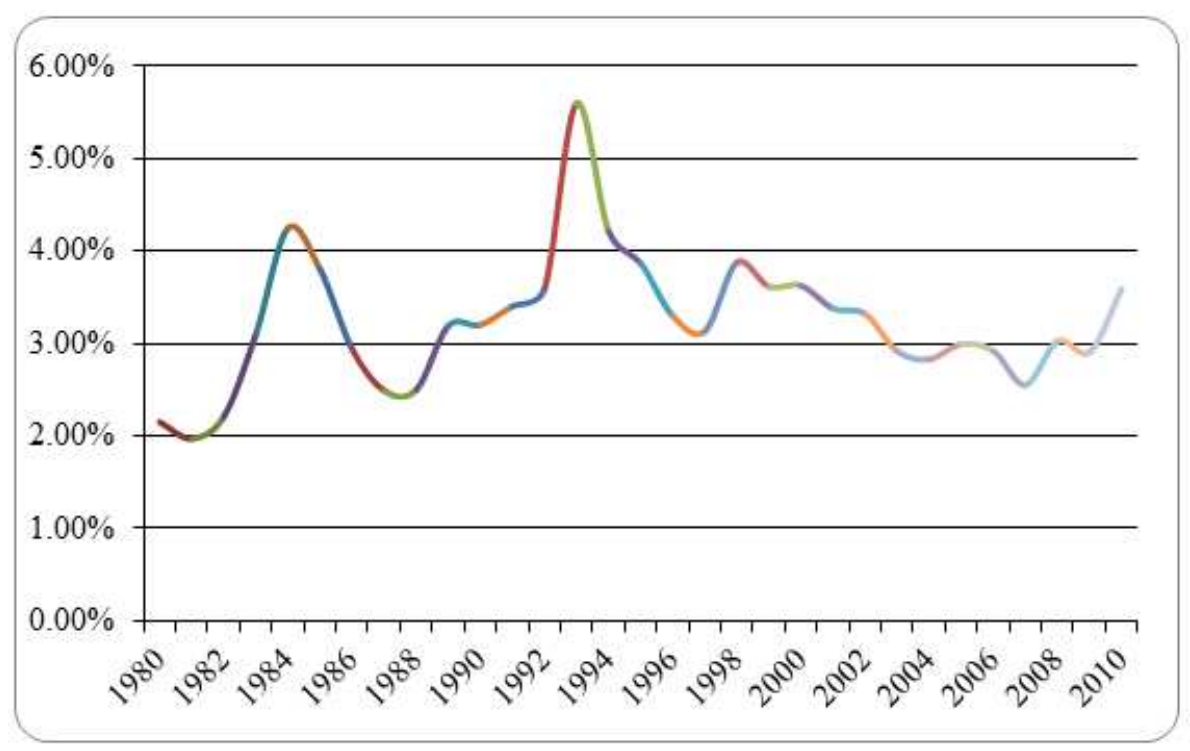

Figure 2. Kenya tea export earnings/GDP: 1980-2011. 
Tea export earnings over the period 1980 - 2011 have experienced fluctuating upward trend. This consequently affects the profitability of firms in the sector and therefore farmers' earnings (bonus). To this end, there is dire need for stabilizing the earnings to farmers hence need to know the key factors which could be targets for policy and hence the need for this study. This study gives an account of various determinants of tea export earnings in Kenya. Given the problem of fluctuation of economic variables, the objective and purpose of this study is to investigate how such fluctuations affect the value of tea exports in Kenya which is the chief foreign exchange earner for the Kenyan economy. Figure 3 demonstrates progressive tea export earnings over the period $1980-2010$.

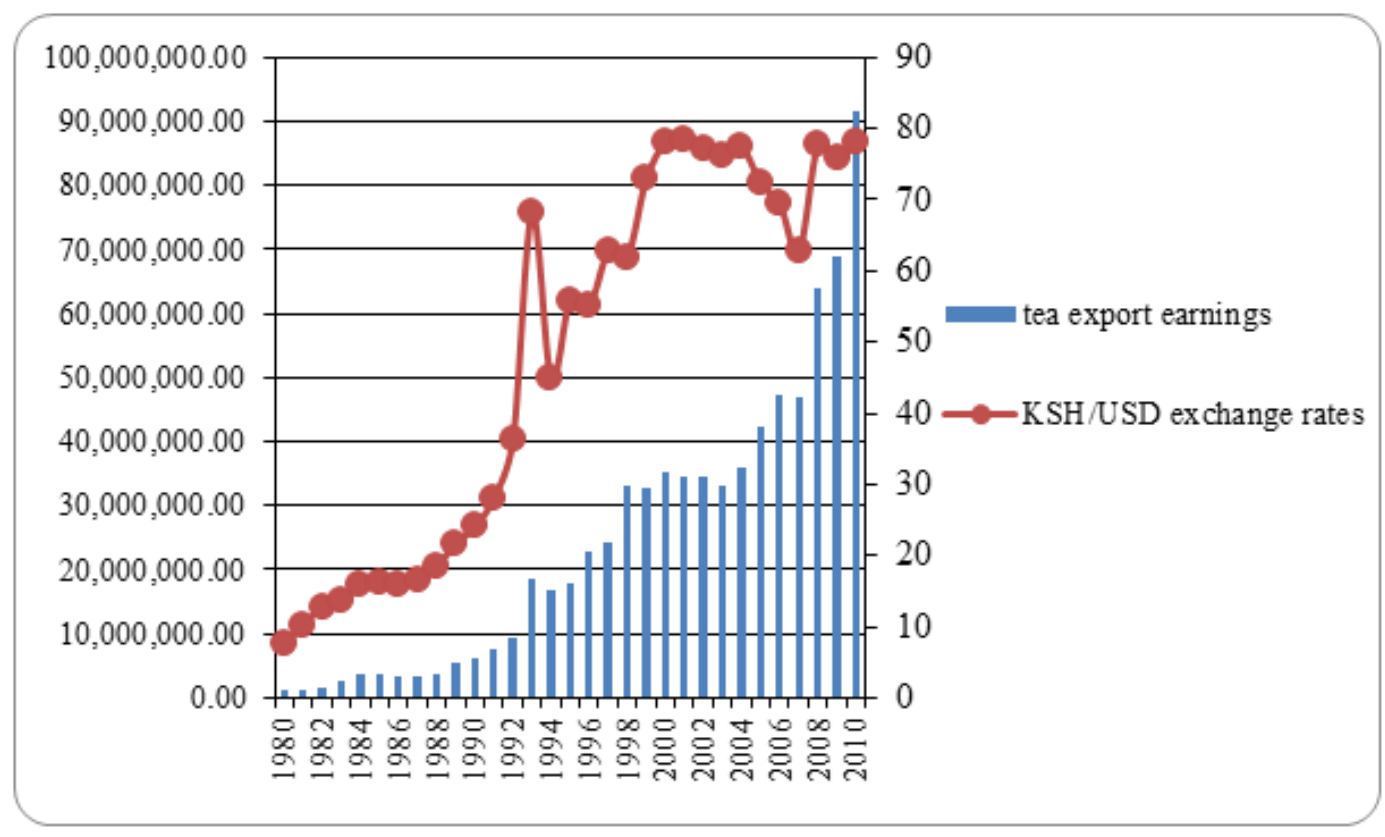

Figure 3. Kenya's Tea export earnings v nominal exchange rate: 1980- 2010.

Ministry of Agriculture (2009) indicates that export of agricultural products has faced restrictions due to poor packaging/ value addition, damage during transportation, poor handling and infections due to lack of a Code of Conduct for exporters, and quality control. However, this study ignores these and the issue of trade policy credibility and taxation. It follows that the study gives a quantitative account of the determinants of tea exports. The broad objective of the study is to investigate the determinants of tea export earnings in Kenya. The specific objectives are:

i). To explore the effect of real exchange rate on tea export earnings.

ii). To establish the effect of inflation rate in Kenya on tea export earnings.

iii). To establish the effect of foreign income of major trading partners on tea export earnings

\section{Literature Review}

The most commonly held belief is that greater exchange rate fluctuation generates uncertainty thereby increasing the level of riskiness of trading activity and this will eventually depress trade (Todani and Munyama, 2005). Johnson (1969) and Kihangire (2004) as cited by Wesseh and Niu (2012) assert that the birth of this new system of exchange rate has engendered a 'hot' and extensive theoretical and empirical debate regarding the impact of exchange rate variability on foreign trade. Policy makers in many developing countries are puzzled whether they should concentrate on formulating policies that are designed to be export-promotion oriented or import-substitution oriented. If export growth could contribute to economic growth, the former policies are advocated (Oskooee et al., 2005). Ogun (1998); Klaassen (1999); Whitley, (1994); Ndung'u and Ngugi, (1999); Alemayehu, (1999); Balassa et al., (1989); Branchi et al., (1999), Mckay et al., (1998) as cited in Were, et al. (2002) note that conventional commodity models usually incorporate the real foreign income (of trading partners) and real exchange rate (proxy for relative prices) as explanatory variables in the estimation of the export supply functions in general (among others). This study adopts a similar approach. These determinants of tea export earnings are discussed in this section and provide a basis for the model specification in section 3 .

\subsection{Conceptual Framework}

\subsubsection{Foreign Income}

According to the study by Todani and Munyama (2005) industrial production is used as a proxy for foreign income. Therefore, income of trading partners is used as an indicator of potential demand for our tea exports. However, the study indicates that GDP, disposable income or any other national income measure for major trading partners can be used as a measure of income. The real foreign income is a weighted 
average of the real GDP of respective trading countries. Real GDP is calculated by dividing the nominal GDP of each country by the GDP deflator with base year 2000 of the respective countries. The weight used is as calculated above (Ragoobur and Emamdy, 2011). Arora and Vamvakidis (2004) state that a general implication of the results is that industrial countries benefit from trading with developing countries, which grow rapidly, while developing countries benefit from trading with industrial countries, which have relatively high incomes. Were et al., (2002) highlight that real income of trading partners is computed as GDP volume index for Kenya's major trading partners weighted by export share.

\subsubsection{Real Exchange Rate (Proxy for Relative Prices)}

Bilateral trade between two countries depends upon, among other things, exchange rates and the relative price level of the two partners (Todani and Munyama, 2005). Writing in the same vein, Rowlatt (1992) indicate that the price competitiveness of one economy's goods compared to those of another is indicated by the real rate which the currencies are exchanged. The real exchange rate was computed using the traditional approach as follows under ceteris paribus conditions:

$$
\mathrm{RRX}=\mathrm{RX} \times\left(\mathrm{P} \div \mathrm{P}^{\mathrm{w}}\right)
$$

Where:

$\mathrm{RRX}=$ Real Exchange rate,

$\mathrm{RX}=$ Nominal exchange rate,

$\mathrm{P}=$ domestic CPI, and

$\mathrm{P}^{\mathrm{w}}=$ foreign $\mathrm{CPI}$.

Globally there is overproduction and oversupply of tea on the international markets. This together with poor and cheap quality teas from other countries has led to a drop in world tea prices. Kenya being a leading producer and exporter has been directly affected (CPDA, 2008). In fact, Visor (1995) indicates that devaluation makes the domestic price level rise and resistance against devaluations is often based on a fear of accelerating inflation. Exchange rates are determined not simply by the stance of monetary policy, but depend in a complex and as yet little understood manner upon the monetary/fiscal policy mix and the interactions of these macroeconomic policies between countries (Pilbeam, 1998).

According to Rowlatt (1992) the price competitiveness of one economy's goods compared to those of another is indicated by the real rate which the currencies are exchanged. The real exchange rate, which reflects the underlying relative movement of prices at home and abroad, proves to have a significant effect on the export performance of the lowest performers (UNCTAD, 2005). To model exchange-rate movements is to presume that the foreign exchange market is efficient in the sense that all ex ante profit opportunities are eliminated (Pilbeam 1998). World Bank (2011) points out that the weakening of the shilling has translated into only marginal benefits for exporters.

\subsubsection{Inflation}

De Grauwe (1996) point out that one of the mechanisms in the flexible exchange rate system which could in principle have stimulated inflation has been stressed .One is ratchet effect the other is discipline effect. The hypothesis that the path of the exchange rate is to consistent with PPP is an example of the general principle that behaviour is determined by real variables rather than nominal ones. However, there are a number of theoretical reasons why this hypothesis cannot be expected to explain the short-term path of the nominal exchange rate, quite apart from the fact that the data fail to lend it support. First, the Law of One Price can only apply to the prices of traded goods; it can be of little direct significance to goods for which transport costs make export impractical or to services which must be consumed in the country in which they are produced. Second, even if traded goods' prices approximately broadly to the level implied by the Law of One Pride, it would not necessarily follow that PPP determined the path of the exchange rate (Rowlatt, 1992).

\subsubsection{Real Tea Exports}

This study depicts real tea exports by the value of earnings from tea exports. According to Todani and Munyama (2005) real exports are constructed as nominal exports deflated by the CPI. Following Aziakpono, et al. (2005) and Sekantsi (2007) this study express Kenya tea exports in real terms by deflating them using the CPI of major tea trading partners (UK, Pakistan and Egypt). Although, economic theory requires that quantity rather than value be used, we use this in value terms in order to determine earnings from tea exports.

\subsection{Empirical Evidence}

Alemayehu (1999) as cited in Were, et al. (2002) points out that from the literature available, the factors that determine the supply of primary commodity exports include cost and accessibility of consumer goods, farm subsidies and taxes, research and extension, infrastructure, access to credit, among others. Although literature on commodity export supply functions starts from structural equations, which accommodate a wide spectrum of these factors, the estimated reduced form equations are generally price-focused; they include either current or lagged (relative) prices. The pricefocused supply models stem from Nerlove's (1958) model (Were et. al, 2002). Nerlove describes the dynamics of agricultural supply by maintaining the assumption that producers are influenced by their perception of normal price, which is captured through adaptive price expectation mechanism. Consequently, production is a function of prices and other adjustment costs.

Were, et al. (2002) study of an empirical evaluation and analysis of Kenya's export performance by disaggregating total exports of goods and services into three categories: traditional agricultural exports (tea and coffee) and 'other exports of goods and services'. For each of the three categories of exports, an empirical model is specified along the standard trade models that incorporate real exchange rate (proxy for relative prices) and real foreign income (of major trading partners) as explanatory variables. An additional 
variable (investment as a proportion of GDP) is included as a proxy to capture the supply constraints. An error correction formulation is used to distinguish between the long-run and short-run elasticities. In the case of tea, the results were found to be inconsistent- - no co integration and therefore no error correction model. However, in general, real exchange rate has a profound influence on export performance. The supply response to price incentive (real exchange rate depreciation) for exports of goods and services is significant. On the other hand, the other explanatory variables provided mixed results. Investment as a proportion of GDP used as a proxy for supply constraints had a positive and significant impact on the export volumes of coffee but not for exports of other goods and services.

Todani and Munyama (2005) study on exchange rate volatility and exports in South Africa. This paper examines the characteristics of short-term fluctuations/volatility of the South African exchange rate and investigates whether this volatility has affected the South Africa's. They cite following Arize et al. (2000) and de Vita and Abbott (2004), amongst others, and specify a demand equation where real exports is a function of relative prices; income of trading partners as an indicator of potential demand for our exports; the exchange rate volatility and measures uncertainty associated with fluctuations in the exchange rate. The econometric technique employed for quarterly data for the period 1984 to 2004 is the autoregressive distributed lag (ARDL) bounds testing approach to co integration proposed by Pesaran et al. (2001). The results show the sensitivity of the models to the variable definitions used.

They find that, depending on the measure of volatility used, exchange rate volatility either does not have a significant impact on South Africa's exports flows or it has a positive impact does have a positive impact on aggregate and goods exports. From the aggregate/total exports models (long run analysis), three observations are clear. First, all income coefficients, as expected have positive signs implying that increases in incomes of South Africa's trading partners generates an increase in South Africa's exports. However, these coefficients are statistically insignificant. Second, the coefficients on relative prices all have the wrong negative signs and are all statistically insignificant at conventional level of significance. As for the short run dynamics i.e. error correction regressions associated with models estimates provide additional evidence on the complicated and often inconsistent dynamics that exist between real exports and its main determinants. The coefficients on $\mathrm{ECM}_{\mathrm{t}-1}$ in both models are statistically significant and negative as expected and support the validity of the equilibrium relationship between the variables in the long run equations.

Sekentasi (2007) research paper empirically examines the impact of real exchange rate volatility on trade in the context of South Africa's exports to the U.S. for the South Africa's floating period January 1995-February 2007. In measuring real exchange rate volatility, this study utilised GARCH. Results established negative relationship between real exchange rate volatility and South African exports to the
United States indicates that GARCH class models can capture volatility correctly and can therefore act as a good measure of volatility.

Wesseh and Niu (2012) research paper empirically investigates the impact of exchange rate volatility on trade in the context of South African exports to China by means of ARDL bounds testing procedure to co integration developed by Pesaran, et al. (2001). Several alternative measures of short-term exchange rate risk were employed in which we selected for each equation, the 'optimal' ZAR/CYN volatility measure on the basis of relevant model selection criteria. Using both monthly and quarterly data disaggregated by sectors for the period 1992M1 to 2010M7 and 1995Q1 to 2010Q3 respectively, our results indicate that South African exports to China, at aggregate level, are generally income inelastic, relative price elastic, and largely unaffected by short-term exchange rate volatility. However, when data are disaggregated by sector, the demand for South African exports tends to be income elastic; and in the case where a significant relationship exists between exchange rate volatility and exports, such a relationship is either positive or negative. These results can be generalized to how ZAR/USD volatility impacts on South African-China trade.

Ragoobur and Emamdy (2011) research paper empirically investigates the impact of real effective exchange rate volatility on the Mauritian export performance from 1975 to 2007 . Exchange rate volatility is derived from the moving average standard deviation method since no GARCH effect was obtained. The empirical results based on the ARDL analysis show that real exports are co integrated with foreign economic activity, real effective exchange rate and volatility of real exchange rate. Our findings reveal that exchange rate volatility has a positive and significant short run effect on exports, whilst in the long run; volatility adversely affects the Mauritian exports. It thus becomes crucial to consider both the existence and the degree of exchange rate volatility for the implementation of appropriate trade policies to improve the country's export performance and trade balance.

On a study done on analyzing the impacts of trade liberalization on Sub-Saharan African export performance Babatunde (2009) used panel data set from 1980 - 2005. Model used was panel-fixed effect and random effect concluding that the panel evidence supports the view that the real effective exchange rate is an important factor affecting export performance in SSA.

\section{Methodology and Estimation}

This is a longitudinal research time series aimed to achieve the broad objective of the study which is to investigate the determinants of tea export earnings in Kenya over the period 1980 to 2011.

\subsection{Model Specification}

This section gives a brief discussion of the econometric model to be used in estimating the determinants of tea export 
earnings in Kenya. Control variables applied in the study are the unit prices of tea exports; export of goods and services (current USD); and agriculture value added (current USD). To this end, the following equation is to be estimated:

$$
\begin{gathered}
\mathrm{LN} \_\mathrm{X} t \mathrm{t}=\beta_{0}+\beta_{1} \mathrm{LN} \mathrm{Y}_{\mathrm{t}}+\beta_{2} \mathrm{LN}_{-} \mathrm{RER}_{\mathrm{t}}+\beta_{3} \mathrm{LN}_{-} \mathrm{INF}_{\mathrm{t}}+\beta_{4} \\
\mathrm{LN} \mathrm{P}_{\mathrm{t}}+\beta_{5} \mathrm{LN} \mathrm{LGV}_{\mathrm{t}}+\beta_{6} \mathrm{LN}_{-} \mathrm{XGS}_{\mathrm{t}}+\varepsilon_{\mathrm{t}} ;
\end{gathered}
$$

Where:

LN_X $\mathrm{X}_{\mathrm{t}}=$ Natural logarithm of Kenya's Real tea export (nominal exports deflated by CPI)

LN_Y $Y_{t}=$ Natural logarithm of real foreign income (UK, Egypt's and Pakistan's GDP deflated by CPI). This is used as an indicator of demand for tea export.

$\mathrm{LN}_{\mathrm{NER}}=$ Natural logarithm of real exchange rate

LN_INF $F_{t}=$ Natural logarithm of Kenya's inflation rate

${ }_{L N} \mathrm{P}_{t}=$ Natural logarithm of unit prices of tea exports

LN_AGV ${ }_{t}=$ Natural logarithm of agriculture value added (current USD).

LN_XGS $\mathrm{t}_{\mathrm{t}}=$ Natural logarithm of export of goods and services (current USD)

$\beta_{0}=$ intercept parameter

$\varepsilon_{\mathrm{t}}=$ stochastic error term

\subsection{Data Sources}

This research study sources secondary data from Tea Board of Kenya (TBK), Kenya National Bureau of Statistics (KNBS), and World Bank database. These institutions are custodians of authentic data that is used by economists and other researchers. KNBS publications such as the Economic Survey and Statistical Abstract, over the period of study, were used to extract data required. Whilst TBK provided data on the destination of Kenya tea 1994 - 2011; this helped to ascertain the tea export share of major trading partners. Data required for the success of this study empirical analysis include the nominal exchange rate KES/ USD, CPI Kenya, Egypt, UK and Pakistan that was used to compute real exchange rate. The GDP Egypt, UK and Pakistan were used to compute foreign income using their respective ratios. Another important data variable used is domestic inflation rate.

\section{Data Analysis, Results and Discussion}

Empirical results are analyzed and presented in this section. The methods used and findings are discussed in detail.

\subsection{Unit Root Tests}

The use of nonstationary variables in the time series analysis leads to misleading inferences. To avoid spurious model due to trending variables, unit root test was carried out. This study uses the traditional Augmented Dicker Fuller (ADF) test to check for the unit root in each variable and thereby determine the order of integration as shown below.
Table 1. Test for Unit Roots.

\begin{tabular}{lll}
\hline Variable & $\begin{array}{l}\text { ADF Test Variable in } \\
\text { Levels }\end{array}$ & ADF Test on Fist Difference \\
\hline X & - & $\mathrm{I}(1)$ \\
Y & - & $\mathrm{I}(1)$ \\
$\mathrm{INF}$ & $\mathrm{I}(0)^{*}$ & - \\
$\mathrm{P}$ & - & $\mathrm{I}(1)$ \\
AGV & - & $\mathrm{I}(1)$ \\
XGS & - & $\mathrm{I}(1)$ \\
\hline
\end{tabular}

*INF is tested using both ADF and PP Tests.

Further tests were carried out on the INF variable using PP Tests for stationarity and the results reflected the PP Test variable in levels. This confirms that indeed the variable is stationary. Real tea exports, real exchange rate, foreign income, unit price of tea exports, agriculture value added and export of goods and services are integrated of order 1 .

\subsection{Long-Run Analysis}

With D-W stat of 2, it shows that there is no serial correlation and therefore the model gives a good description of the variables. Results shows that $1 \%$ increase in foreign income causes $0.36 \%$ decrease in tea export earnings. This shows there is an inverse relationship between foreign income and tea export earnings. $t$ statistic is -1.02 which is less than 2; showing that foreign income is insignificant. $1 \%$ increase in RER results to $0.3 \%$ decline in tea export earnings. $t$ statistic is -0.8 meaning RER is an insignificant variable in determination of tea export earnings. $1 \%$ increase in inflation causes $0.07 \%$ decline in tea export earnings. $t$ statistic is -1.5 which is less than 2 . Therefore inflation is insignificant in determination of tea export earnings.

\subsection{Engel- Granger Two Step Procedure}

The next step is to examine whether the integrated variables are co integrated. Modeling using variables in the first difference to achieve stationarity leads to loss of longrun information. The concept of co integration implies that if there is a long-run relationship between two or more nonstationary variables, deviations from this long-run path are stationary. The results indicate stationarity at levels. Therefore, there is co integration.

\subsection{Johansen's Cointegration Test}

Johansen's co integration multivariate procedure is used to establish whether the variables are co integrated in the long run. The results show that there are at most 4 cointegrating variables in the long run. They have long run association such that they move together. According to the study by Were et al. (2002), in the case of tea, the results were found to be inconsistent-no co integration and therefore no error correction model.

\subsection{Error Correction Model}

This paper further used the ECM representation to investigate the short run dynamics. With D-W stat of 2.0, it 
shows that there is no serial correlation and therefore the model gives a good description of the variables. There was about $74 \%, 0.9 \%$, and $60 \%$ of disequilibrium "corrected" annually by changes in real exchange rate, inflation and foreign income respectively. Further, all variables have positive coefficients with the exception of foreign income. There is a direct relationship between tea earnings and the following variables: real exchange rate, export of foods and services, tea price, agriculture value addition. On the other hand, there is an indirect relationship between tea earnings and income of major trading partners. All variables regressed are significant with the exception of inflation.

\section{Conclusion and Policy Implication}

As depicted in similar studies, this paper acknowledges that non-price factors such as costs of inputs, labour costs, and access to credit play a vital role in production and export supply response. Nonetheless, the results of this study are quite informative and arguably point out several issues of policy concern. The research questions answered in the investigation include exploring the effect of real exchange rate on tea export earnings; establishing the effect of inflation rate in Kenya on tea export earnings; as well as, establishing the effect of foreign income of major trading partners on tea export earnings.

Relationship between tea export earnings and real exchange rate is positive in the short run. This means that increase in real exchange rate caused by depreciation of the Kenya shilling against the USD results in high tea export earnings. Appreciation of the Kenya Shilling against the dollar as a result of decline in the real exchange rate leads to a decline in tea export earnings. This is a significant variable in realization of tea export earnings. However tea prices at the Mombasa tea auction are significant both in the short run and in the long run.

The results suggest that there is a negative relationship between tea exports and foreign income both in the long run and short run. This means that an increase in foreign earnings result to a decline in tea export earnings. Increase in the national income of UK, Egypt and Pakistan may result to diversion of spending to other priority sectors of the respective economies other than tea imports. This is a significant variable in realization of tea export earnings. In addition, agriculture value addition is significant in the realization of tea export earnings.

There is a direct relationship between tea export earnings and domestic inflation in the short run whereas there is an inverse relationship in long run. Continued inflation will result to high cost of production due to pricy inputs. Given that the tea fertilizer is imported, gains earned from exporting are equally offset causing tea export earnings to decline. Models used indicate that inflation is an insignificant variable in tea earnings. Noteworthy, like in the literature especially for developing countries, there are some inconsistenciesmost econometric time series studies often fail to find robust estimates-for example wrong signs and insignificant price coefficients (Were et al., 2002).

Exchange rate is a significant variable in determination of tea export earnings. Fluctuation of exchange rate may result to an anticipated loss for the Exchange rate risk takes several forms and, in the absence of fixed exchange rates or monetary union, firms must take action to protect them against that risk. The need for sophisticated risk management in the face of highly volatile exchange rates provides one of the principal reasons for the growth of derivatives markets. These allow firms to hedge risk by taking out contracts in derivatives markets, which carry the opposite risk to that faced in the underlying markets such as the forex markets. The two principle types of derivatives are futures and options. The Nairobi Securities Exchange is in the process of launching futures. This is an opportunity for tea exporters to hedge against foreign exchange risk.

With advances in economic integration, particularly the EAC and COMESA, together with African Growth Opportunity Act (AGOA), there are opportunities to explore more potential export markets for tea exports from Kenya. This can be achieved through promotion of value addition for tea originating from Kenya as opposed to exporting raw black tea. The study shows that an increase in income of major tea trading partners results to decline in tea export earnings. This signals to key stake holders in the sector that value addition is significant to ensure sustainability in the long run. Further, institutions such as the Tea Board of Kenya in partnership with the government institution in charge of promoting international trade have a role in marketing tea originating from Kenya to Pakistan, Egypt, the UK and other countries. This would have significant impact should it be done particularly in the boom economic cycle of the respective countries. This is because targeting such a period when these countries are experiencing economic expansion and higher GDPs. To this end, need to diversify value-added tea products and the development of relevant technologies would enhance farmers' earnings. These measures are also expected to open up new market niches for Kenyan tea.

Establishment of strong macroeconomic policies results to macroeconomic stability in the country. It ensures price stability and curbs the issue of inflation. The authorities need to be able to respond to any such disequilibrium with shortterm intervention in the market as well as adjusting longer term monetary and fiscal policy. This will help to ensure sustainability and subsequent growth in the tea export earnings.

Potential areas of study include an empirical study on effects of exchange rate volatility on Kenya's export performance. This involves panel data analysis of major export commodities that dominate the sector. More specific area of study that follows the train of thought in this particular thesis would be a research on the effects of exchange rate volatility on Kenya's tea export performance. In addition, a research on the peculiarities of tea export demand would focus on demand elasticity of Kenya's tea export. To understand further the demand elasticity of major exports in Kenya a study on the export demand elasticity 
estimation of major exports in Kenya would be a perfect fit. This involves panel data analysis of major export commodities that dominate the sector. Results of these suggestions for further study would potentially point out several issues of policy concern.

\section{References}

[1] African export-import bank (AFRIEXIM). (2011). Annual Report 2010. Egypt: AFRIEXIM

[2] Arora, V., \& Vamvakidis A. (2004). How much do trading partners matter for economic growth? IMF Working Paper WP/04/26. US: International Monetary Funds.

[3] Aziakpono, M, Tsheole, T \& Takaendasa, P. 2005. Real exchange rate and its effect on trade flows: New evidence from South Africa, accessed 21 January 2013, $<\mathrm{http}$ :/www.essa.

org.za/download/2005Conference/Takaendesa.pdf>

[4] Babatunde, M. A. Can trade liberalization stimulate export performance in Sub-Saharan Africa? Journal of International and Global Economic Studies, vol. 2, no. 1, pp. 68-92, 2009.

[5] Bailey, R. E. (2005).The economics of financial markets. UK: Cambidge University Press

[6] Bishop, E. (2001). Finance of international trade. UK: Intellexis plc, Elsevier Ltd

[7] Cechetti, S. (2008). Money, banking and financial markets. (2nd ed.). US: McGraw- Hill Irwin

[8] Christian Partners Development Agency, (2008). Report on small-scale tea sector in Kenya. Kenya: CPDA.

[9] De Grauwe, P. (1996). International money. (2nd ed.). Britain: Oxford University Press

[10] East Africa Tea Trade Association. (2012). Feasibility study and business process reengineering final report. Kenya: EATTA.

[11] Edwards, L., \& Alves, P. (2005). South Africa's Export Performance: Determinants of export supply. Africa region, World Bank working paper 95. US: World Bank

[12] Eun, C. \& Sabherwal, B. R. (2012). International Finance. US: US: McGraw- Hill Irwin

[13] Gomez, C. (2008). Financial markets, institutions and financial services. Newdelhi, India: PHI Learning Private Ltd.

[14] Gujarati, N 2003, Basic econometrics, (4th Edition). New York: McGraw Hill.

[15] Howells, P., \& Bain, K. (2000). Financial markets and institutions. (3rd ed.). UK: Pearson Education Ltd

[16] Kenya Vision 2030. (2007). Kenya: Government of the Republic of Kenya

[17] Korathi, C. (2005). Research methodology. (2nd ed.). India: New Age International (P) Limited, Publishers
[18] Ministry of Agriculture, (2009). Strategic Plan 2008 2012.Kenya: Ministry of Agriculture.

[19] Oskooee, M. B., Economidou, C., \& Goswami, G. G. (2005). Export led growth hypothesis revisited: A panel co integration approach. Scientific journal of Adminstrative Development. Vol. 3. Pp 40-55

[20] Pesaran, M. H., Shin, Y. and Smith, R. J. 2001. "Bounds testing approaches to the analyses of level relationships", Journal of Applied Econometrics, No. 16, pp. 289-326.

[21] Pilbeam, K. (1998). International Finance. (3rd ed.). London, UK: Macmillan Press Ltd

[22] Pingle, R. \& Robinson, M. (2002). E- Money and payment systems review. London: Central Banking Publications Ltd.

[23] Rodriguez, R. M., \& Riehl, H. (1983). Managing foreign and domestic currency operations. US: McGraw- Hill Irwin

[24] Rowlatt, P. A. (1992). Inflation. London: Chapman \& Hall.

[25] Muguika, K. (2007). Foreign exchange and international trade finance. Kenya: Pinnacle Ltd.

[26] Sekantsi, L (2007). The impact of exchange rate volatility on South African exports to the United States (US): A bounds test approach.

$<$ http://www.eiit.org/WorkingPapers/Papers/TradePatterns/FR EIT191.pdf $>$. Last retrieved on 2nd Jan, 2013.

[27] Tea Board of Kenya. (2012). Kenya Tea. Kenya: TBK

[28] Tea Research Foundation of Kenya. (2011). Strategic Plan 2010 - 2015. Kenya: TRFK

[29] Tea Research Foundation of Kenya. (2007). Strategic Plan 2005 - 2010. (2nd ed.). Kenya: TRFK

[30] Tenreyro, S 2004 'On the trade impact of nominal exchange rate volatility', Federal Reserve Bank of Boston, Working Paper 03-2.

[31] Todani, RK \& Munyama, T 2005, Exchange rate volatility and exports in South Africa, accessed 25 January 2013 ,Trade and Industry Policy, <http://www.tips.org.za/files/773.pdf.>

[32] Visser, H. (1995). A guide to international monetary economics: Exchange rate systems and exchange rate theories. England: Elgar Publishing Ltd.

[33] Vergil, H., 2002. Exchange rate volatility in Turkey and its effects on trade flows. Journal of Economic and Social Research, 4 (1), pp. 83-99.

[34] Wesseh, P. K., \& Niu, L. (January, 2012). The impact of exchange rate volatility on trade flows: New vidence from South Africa. International Review of Business Research Papers. Vol. 8. (1). Pp. 140 - 165

[35] Were, M., Ndung'u, N., Geda, A., \& Karingi, S. (2002). Analysis of Kenya's export performance: empirical evidence. KIPPRA Discussion Paper No. 22. Kenya: KIPPRA

[36] World Bank. (2011). The state of Kenya's economy. US: World Bank 